\title{
A Step towards Building Environmental Protection Strategy: Game Theory Framework for Al-Abrash River Basin Management
}

\author{
Tarek Rahmoun and Mohammed Rahmoun
}

\begin{abstract}
The current random behavior of stakeholders within the Al-Abrash river basin in Syrian coastal region, the lake and the river, threatens more than ever to pollute the whole basin. The goal of this paper is to address the state of shared management of water resources among local players through game theory application based on two self-interest strategies for each player to reach a balance point taking into consideration the government intervention as the organizer of the game. Therefore, non-cooperative game theory NCGT adopted as an analytical approach for modeling planning assets conflicts. ArcGIS software adopted to define different areas according to its risk/land-use types. The result shows that the equilibrium point "non-cooperate-non-cooperate" strategy between the players could lean towards "cooperative-cooperative" strategy in the light of the provincial government effect, adopting innovating competitive planning policies. That will lead to an interactive economical-environmental balance in the river basin and helps to reach rational decisions. Therefore, this paper could be classified as one of the studies seeking to apply the participatory planning approach toward sustainable development.
\end{abstract}

Index Terms-Al-Abrash river basin, environmental protection strategy, game theory, participatory approach.

\section{INTRODUCTION}

River Basins offers an essential geography unit for sustainable development, considering, that human settlements built within a watershed area record stronger physical, social, and economic ties with each other compared to settlements found outside the basin area. Mountain peoples around river watersheds are also an indispensable part of the basin ecology, their impact on the environmental changes on the basin is increasing day by day, and even it's directly affecting the ecological balance and development of the basin [1], [2]. Hence, in this unit, and to establish the linkage between natural/planning assets, i.e., Land/water resources, population/stockholders, the coordination of benefits, and sustainable development should be taken in count [3]. The human settlements environmental system in the basin is an organic synthesis of natural resources environment system and social economic system [1,] [4]. Nevertheless, the deterioration of river watershed/basin sources seems to be going through quickly, particularly in developing countries

Manuscript received October 14, 2018; revised December 12, 2018. This work was supported in part by the National Natural Science Foundation of China $(\mathrm{CN})$ under Grant 51678086.

The authors are with Faculty of Architecture Urban Planning. Chongqing University. Chongqing, China (e-mail: tarek.rahmoun@qq.com, mhd-rahmoun@hotmail.com).
[5], due to the pollution from human activities and rapid climate change. Nowadays planners recognize that river basins/watershed management should take into consideration the fact that it is a combination of both human and biophysical processes [6]. The intricate interactions can have far-reaching harmful effects on the environment, as well as on economic activities [7].

Moreover, conflict analysis researches and coordinating local resources utilization have shifted into more specialized analysis [8]. In term of river basin/watershed management, the conflict between the economic gains resulting from the land-use development of economic/social objectives "tourism, agriculture, industry, and recreational activities", and hot environmental topic "water pollution control" has been apparent [9]. Moreover, river basins form an emerging environmental case study to reach multiple formulas for an integrated eco-management of the basin between the actors "players" and the local governments. One of those forms is the game theory [10], [11].

In the other hand, regional planning, in its' connections, is based on coordination the competitive interaction between the possible planning asset. Especially in developing countries, and specifically in the regions which have a high sensibility like rivers basins, where the relationship between human activities and environmental elements is on a significant level of sensitivity.

Hence, this paper is trying to implicate game theory analysis on Al-Abrash River Basin in the coastal region of Syria, where players are making their decisions independently without any communication with each other to achieve their maximum interests. And then arrange following strategies according to decisions of all influential players according to a mathematical matrix to reach a state of balance. At the point of balance, players believe that they have achieved their best interests under environmental and legislative conditions within the study area. The strategies of industrial, agricultural and tourism developments, besides of environmental protection in light of their relation to each other and their geographic placed according to the basin will be recognized. Hence, this paper will focus on the basic cognition and coordination of river basin and the identification and assessment of ecological security in the target area. The paper concludes with the proposal for future guideline planning and intervention of living environment in the target river basin. Thus, it could be the first contribution on the coordination of non-cooperative planning relations within a specific geographic unit in Syria by using game theory approach, which will lead to best solutions to achieve environmental protection within the most important water 
tank at the national level, viz the coastal region.

\section{MATERIALS AND MethodS}

\section{A. Game Theory Approach}

The first citation of the game theory goes back to 1913 when Ernst Zermelo, a German mathematician, published a paper taking the chess game as an illustration of the two-person game of strategy, where chance is not taking any role in decision making or the final result [12]. Chess, as a game, is considered a "perfect information" game, where all players have perfect knowledge of game structure, rules, and situation, it's also an example of "zero-sum game" where there is only one winner. Neumann showed in 1926 in a paper called "Theory of Parlor Games" that in two-person zero-sum games you can always figure the best strategy to increase your profit to the maximum or to limit loses depending on the game rules and your opponent strategies [12].

In 1944 John von Neumann and Oskar Morgenstern published the book "Theory of Games and Economic Behavior" which a lot consider it one of the greatest scientific accomplishes in the first half of the twentieth century. This book lays out the foundation of game theory leaving much to enhance, as it is considered one of its advantages, especially relating to economic and mathematical field [13]. After that, specifically in 1949, John Nash's paper about non-cooperative games came along to repute the game theory on the table again. Nash's equilibrium formula presented to the fields of economy and political science what DNA discovery did for biological science [14].

Nash equilibrium in words is the best set of strategy a player can make in response to the others. Or as Samuel Bowles says the Nash equilibrium "is a situation in which everybody is doing the best they can, given what everybody else is doing." Nash basically reintroduce social science to the worldwide giving a basic analytical structure to study all conflict and cooperation situations [12]. Roger Myerson says: "The theory of non-cooperative games that Nash founded has developed into a practical calculus of incentives that can help us to better understand the problems of conflict and cooperation in virtually any social, political, or economic institution" [14].

Thus, the game theory has been widely applied in economic, social, political, biological, and other sciences to help people analyze social, behavioral phenomena [15]. That's because game theory is a mathematical model of strategic interaction and also a participatory decision-making process, which seeks to recognize optimal strategies at equilibrium threshold among many players who make choices that influence on the gains of other players [16]. One the other side, non-cooperative game theory NCGT is an important source of models for policy-making. Among the applications of NCGT in a multi-fields, many models have been proposed in the environmental study. NCGT gives solid tools for analyzing planning assets thanks to deal with situations requiring multiple-decision-makers, whose objectives fully or partially conflicted with each other; River basins/water resources problems fit into this area. The level of benefit that each player earns depends on its action, also on the choices of the other players. The mathematical equations of all games are similar, and the decision variables are shared by the different goals. Moreover, determining a game requires identification of the players, besides, identification their alternative strategies and their targets. Formulating a problem as a game is beneficial if the solution, such as Nash equilibrium, leads to new insights on the analyzed problem.

\section{B. Study Case Area: Al-Abrash Basin}

It's considered one of the essential basins in the Syrian coastal region with $250 \mathrm{~km}^{2}$ of area, stems from the eastern $1000 \mathrm{~m}$ high mountains heading west for almost 45 kilometers to the estuary in the Mediterranean Sea, and with 5 to 10 kilometers wide starts from the north-east in the mountainous area and ends in the south-west. Three main areas in the basin could be distinguished, which are the upstream area "400-1000 $\mathrm{m}$ height", the middle basin "100-400 m height", and the downstream area, each with unique geographical features and land use differences, Fig. 1.

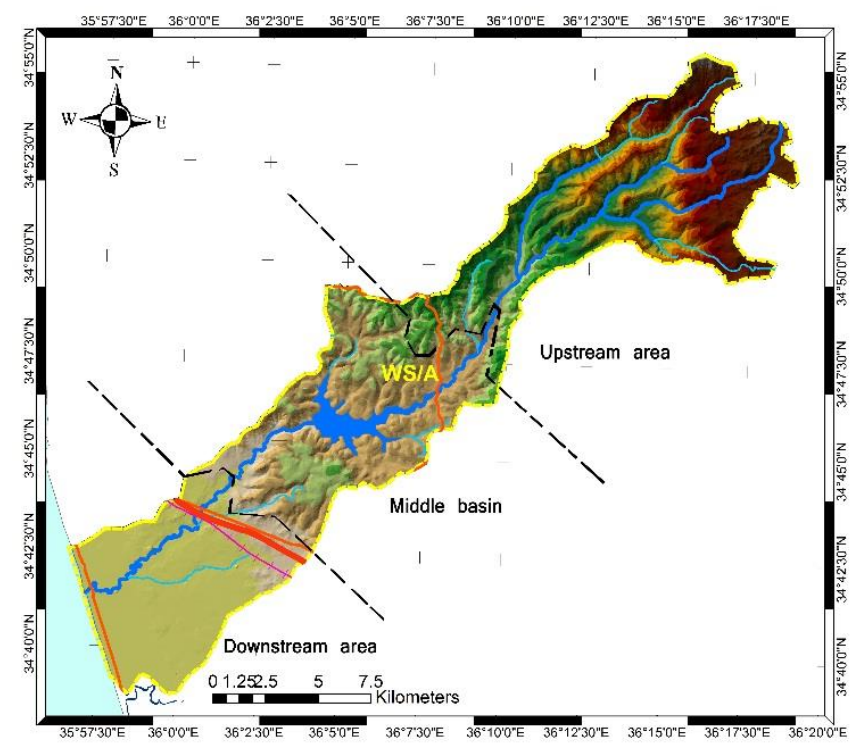

Fig. 1. Case-study area; Al-Abrash River Basin.

\section{ANALYSIS DATA VIA GIS TECHNOLOGY}

\section{A. Human Activities/Assets in the River Basin}

Tourism: The tourism activities centered mainly in the upstream and middle basin. Upstream has a big number of restaurants and hotels, because it's a mountain area and can be used for summer and winter tourism, while in the middle basin and the hills around it characterized by the spread of popular restaurants. On the other hand, there are no tourism activities in downstream except the ones relating to shore tourism. Fig. 2 (a, b). While the middle basin suffers from the negative effects on tourism activity due to high pollution rate of lake water pollution because of sewage waste. In general, the sewage maps show that the wastes of tourism activities/urban-rural settlement are dumped directly into the stream, lake, and the sea without any treatment, Fig. 2 (c). Recently, the sewage treatment plant for settlements north of the lake "Safita district" put under use. Moreover, depending on the information taken from related institutions in the state, and comparing it with current situation plans, it's clear that 
there is an orientation to activate and enlarge tourism role in the basin, especially eco-tourism.

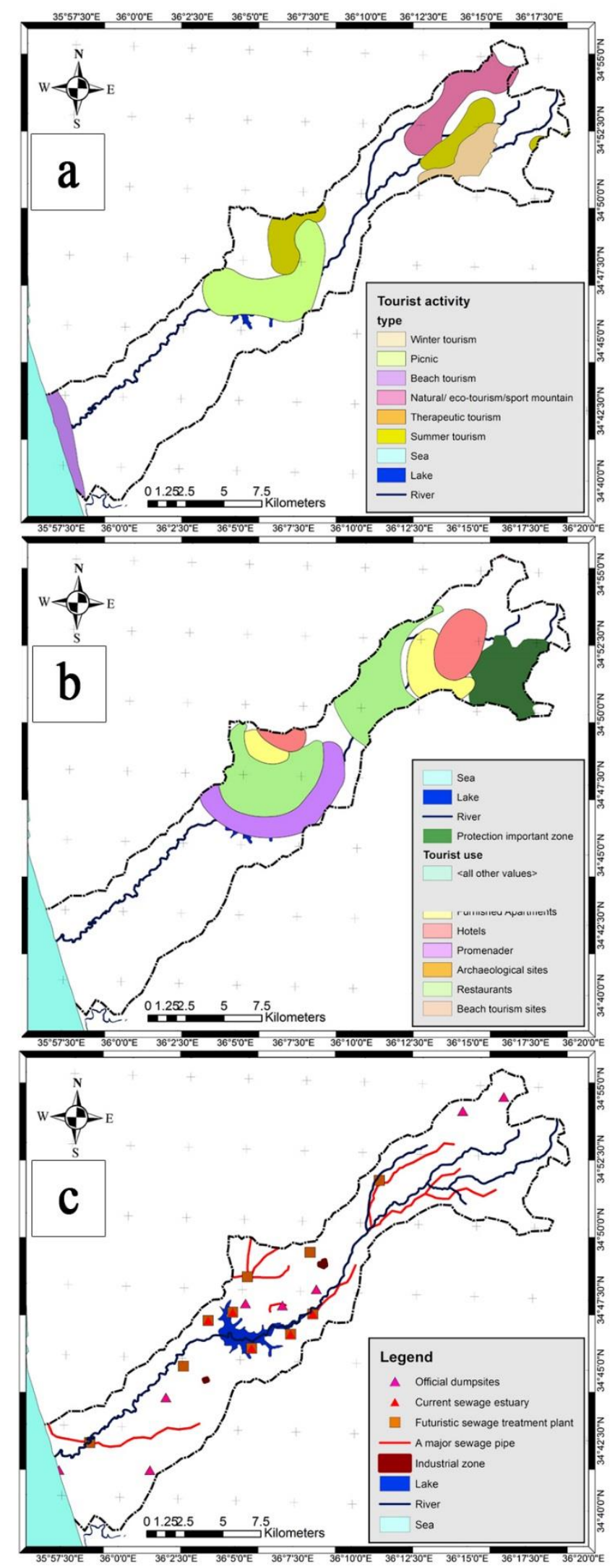

Fig. 2. (a) Tourist activity, (b) Tourism-use, (C) Pollution resources, within study case area. Based on data from Tartous governorate.

Industrial: There are almost no industrial activities in the upstream area, except for some olive mills, because of the nature of plantations focuses on fruit trees and almonds. While, industrial activities and its' waste are mainly centered in the middle basin where there are 21 olive mills in addition to 3 small factories and tow stone quarries, Fig. 3(a). Besides, two small industrials zones planned by the government were licensed last year according to the new environmental regulations "clean industries." The wastes from industry are causing chemical and bacterial pollution, especially seasonal olive mills wastes, leading to the death of fishes and other livings in the lake. It also influences the arable areas which depend on its irrigation on the basin water causing cancers diseases and spreading hurtful odors especially when the lake water level is decreased, due to the increase in temperature "climate change" and evaporating levels.

Agriculture: The basin considered as an agricultural area in the first place, where greenhouses are centered in the downstream and mainly depends on the irrigation network branched from the lake. Rained agriculture is centered in the middle basin, basically, olive trees as strategy agro-product, while in the upper stream there is rained and irrigated plantations depended on canals branched from the river. Fig. $3(a, b)$. Pollution factors are mainly the massive use of pesticides and fertilizers in the agricultural areas.

\section{B. Demographic Distribution}

Al-Abrash river basin contains more than 90,000 people living around the river watershed, distributors over 96 localities between villages, towns, and farms centered in the upstream and middle basin, while it limited in downstream, although, nowadays its agricultural land suffers from urban sprawl phenomenon especially along the regional transport road.

Basin holds six districts, two of them in upstream "Sebei and Mashta Al Helou," and another two in the middle basin "Al-Sisiniyah and Safsafah," in the same time Safita and Al-Hamidiyah influence the basin due to its direct connection to the basin. Fig. 3 (C). This settlement dumps their sewage waste in the basin through 20 non-processor sewage outlet, more than 40 of them don't even have a sewage treatment system. Fig. 2 (C). The direct beneficiaries around the basin "industrial and tourism facilities in addition to agricultural lands and farms" whom we will call "stakeholders," are acting selfishness, considering basin water. Their acts contribute in increasing pollution rates to dangerous levels to maximize their profits, ignoring the negative effects, on the long term, on their interests in the first place, and on the people living in this area and wild environmental in second place. Fig. 4.

The weak interaction of the local districts is useless in the matter of controlling the pollution rates and keeping it in the saved range. On the other hand, stakeholders are not committed to the environmental laws and regulations that organize sewage and pollution problems, due to the absence of the appropriate infrastructure "sewage treatment plants and industrial treatment plants."

\section{RESUlTS AND DisCUSSION}

\section{A. Element of the Game}

Main players in the basin: Thus, the basin is a planning geographical unite, not an administrative unite, because the 
administrative division in the state is not established on the natural geographical dimension. There are many districts manages the basin and representing the administrative authorities, holding the responsibility of the environmental decisions alike. In addition to 78 touristic facilities, 37 olive-mills, 147 Poultry-farm, 7 barns, 18 industrial facilities, and a large number of greenhouses and farms. Besides,

90,000 population and special enterprises contributing to decision-making in the basin.

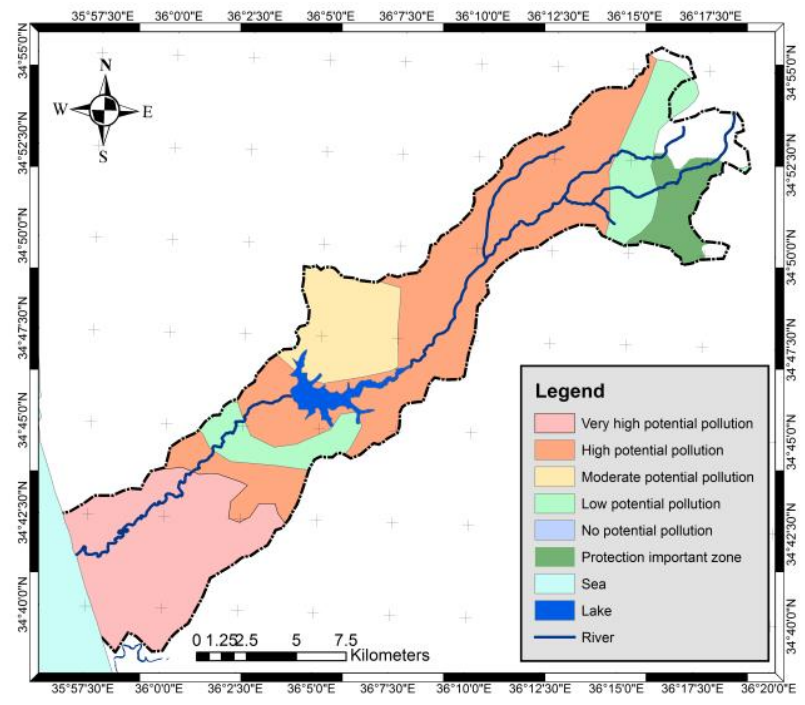

Fig. 3. Study area zones classification by pollution rates.

Every player in the basin have responsibilities and tasks to do, and everyone is developing his strategy to maximize his profits. As written before, we can recognize two clear players, the seven districts from one side, trying to apply environmental laws and regulations, protecting the basin from pollution and coordinate multi-types of activities. On the other side, there are the private enterprises whom not applying environmental operating laws, due to the weak general infrastructure in the basin, trying to maximize their profits by dumping their waste directly to the basin water, without any treatment of these wastes, as a demolition model for natural resources. Moreover, their structures are not equipped for the right kind of waste treatment. For the rest of this paper, we will refer to the seven districts as "BA" basin authorities, and "BS" for the private enterprises.

\section{B. Strategies}

The basin authorities "BA", have their own plan to face the pollution in the basin. Their strategy depends on building the necessary infrastructure which includes household sewage treatment plants, and others for industrial wastewater and olive-mills wastes according to the distribution of these facilities along the basin. Also, to recycle cooling water, building an advanced new irrigation network, and applying strict environmental laws on the private enterprises' facilities. Buildings such big infrastructure plus operating and Maintaining it, is expensive for the "BA" to do it alone, so it faces two strategies:

First strategy is to collaborate with "BS" to finance the project, where the "BA" will construct all the treatment plants and deliver the network into the private enterprises "BS" facilities, in their turn, "BS" will improve their facilities to suit the new sewage network in exchange of decreasing future taxes and waste treatment costs. This will take some of the burdens of the basin authorities and share it with the basin stakeholders. In addition to helping "BA" to raise the public awareness of environmental issues, through integrating them in the process.

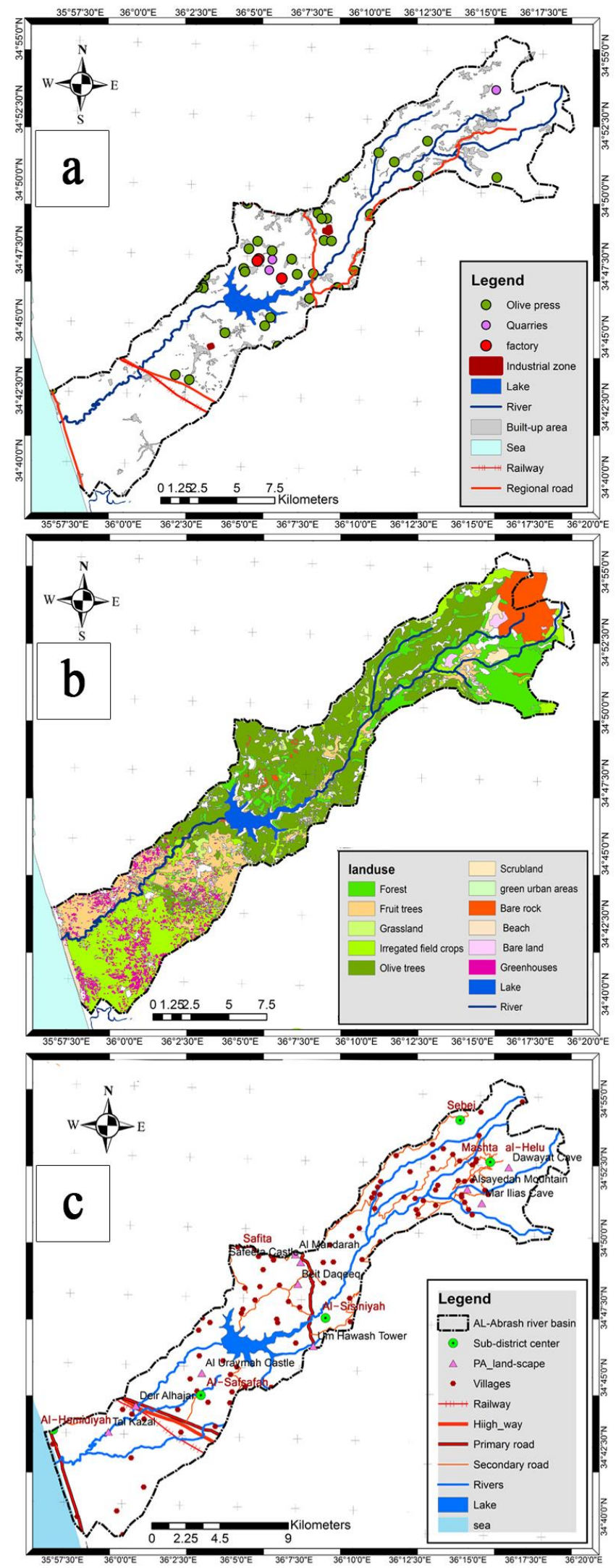

Fig. 4. (a) Industrial location, (b) Land-use, (c) Demographic diffusion within the study-case area. Based on data from Tartous governorate. 
The second strategy is to finance the project through a third party "privet investor" who will build the infrastructure in return of investing all the waste treatment results, in the area, in addition of profits from treating wastes which will be taken from stakeholders "directly". In the other hand, basin stakeholders "BS" strategies will range between collaborating with "BA" which will cost them more, shortly, to enhance their facilities and buying newly developed equipment, to treat the sewage waste and to suit the new sewage network. However, its benefits will be more in the long term considering low taxes, reduction cost on waste treatment, and conserving the lake water from pollution. That means more profit in tourism sector because saving the lake and basin view, and the ability to use it for swimming, camping, and fishing will increase tourism income. Also, agriculture irrigation will depend on treated unpolluted water. The second strategy is to non-collaboration, which will save money for the meantime. Hence, no need to enhance the facilities or to buy the developed treatment equipment, but they will face high taxes and waste treatment cost in the future, in addition of strict monitoring from basin authorities for any violation of environmental laws and regulation.

\section{Payoffs}

Apparently, there are four sets of strategies players can choose from: "BA" and "BS" will collaborate, neither of them will collaborate, and either "BA" or "BS" will cooperate. The payoffs will be measured on a scale from 1 to 6 depending on the economic benefits of the players, in the first place, and on the environmental protection of the basin. Where 1 is the worst payoff, and 6 is the highest.

TABLE I: THE BENEFITS AND LOSSES FOR COOPERATE-COOPERATE C-C STRATEGY

\begin{tabular}{ll}
\hline \multicolumn{1}{c}{ STRATEGY } \\
\hline \hline \multicolumn{1}{c}{ BC: Benefits } & \multicolumn{1}{c}{ BA: Benefits } \\
\hline \hline 1- will buy less taxes & 1- BS will enhance their facilities \\
2- pollution will decrease, and & 2- BS will buy new development \\
lack and basin view will enhance & equipment to treat their wastes \\
3- Tourism movement and & 3- Pollution will decrease \\
agricultural quality will enhance & 4- Public awareness will increase \\
& towards environmental issues \\
& 5- Tourism movement and \\
\multicolumn{1}{c}{ BC: Loses } & agricultural quality will enhance. \\
& 6- Building new irrigation network. \\
\hline \multicolumn{2}{c}{ BA: Loses } \\
1- Extra expenses on buying & \\
2- Extra expenses on facilities & \\
enhancements. & \\
3- Additional expenses to build & \\
new irrigation network & \\
\hline \hline
\end{tabular}

If both players choose the non-cooperate scenario, "BA" will depend on the private investor to build the new sewage network and sewage treatment plants but they will not build the new advanced irrigation network for the agriculture areas in the downstream knowing that the "BS" will not cooperate which will be money lost. "BS" will not enhance their facilities, or building the new advanced irrigation network, keeping their current behaviors and conserving their income profits as it is. This will cost the "BS" more money in the future due to the high taxes which will be applied by the districts. The basin pollution will decrease, as soon the sewage treatment plants work, but not as much as cooperate scenario presents, because current old "BS" facilities will keep dumping their wastes directly to the basin without any treatment. Tables I- II- III- IV show the benefits and loses for the "BC, BA" players in each possible scenario. The payoffs are shown in table 5 , in a simple $2 * 2$ matrix. Each cell has two values representing the payoffs, the left value for the first player "BS", and the second value for the second player "BA". "Higher the number, higher the profit."

TABLE II: THE BENEFITS AND LOSSES FOR NON-COOPERATE-COOPERATE N-C STRATEGY

\begin{tabular}{|c|c|}
\hline \multicolumn{2}{|c|}{$\mathrm{N}-\mathrm{C}$} \\
\hline BC: Benefits & BA: Benefits \\
\hline $\begin{array}{l}\text { 1- They will buy less taxes } \\
\text { 2- pollution will decrease, and lack } \\
\text { and basin view will enhance } \\
\text { 3- Tourism movement and } \\
\text { agricultural quality will enhance } \\
\text { 4- They will not buy developed } \\
\text { treatment equipment. } \\
\text { 5- They will not enhance their } \\
\text { facilities enhancements. } \\
\text { 6- Not building new irrigation } \\
\text { network (cut expenses). }\end{array}$ & $\begin{array}{l}\text { 1- Pollution will decrease (not as } \\
\text { much C-C strategy). } \\
\text { 2- Tourism movement and } \\
\text { agricultural quality will enhance. }\end{array}$ \\
\hline BC: Loses & BA: Loses \\
\hline & $\begin{array}{l}\text { 1- BS will not enhance their } \\
\text { facilities } \\
\text { 2- BS will not buy new development } \\
\text { equipment to treat their wastes } \\
\text { 3- Public awareness will not increase } \\
\text { towards environmental issues. } \\
\text { 3- Building new irrigation network, } \\
\text { without cooperation from BS }\end{array}$ \\
\hline \multicolumn{2}{|c|}{ Payoff $(6-2)$} \\
\hline
\end{tabular}

TABLE III: THE BENEFITS AND LOSSES FOR COOPERATE-NON-COOPERATE C-N STRATEGY C-N

\begin{tabular}{|c|c|}
\hline BC: Benefits & BA: Benefits \\
\hline $\begin{array}{l}\text { 1- pollution will decrease, and } \\
\text { lack and basin view will enhance } \\
\text { 2- Tourism movement and } \\
\text { agricultural quality will enhance }\end{array}$ & $\begin{array}{l}\text { 1- BS will enhance their facilities } \\
\text { 2- BS will buy new development } \\
\text { equipment to treat their wastes } \\
\text { 3- Pollution will decrease } \\
\text { 4- Public awareness will increase } \\
\text { towards environmental issues } \\
\text { 5- Tourism movement and } \\
\text { agricultural quality will enhance } \\
\text { 6- Not building new irrigation } \\
\text { network (cut expenses). }\end{array}$ \\
\hline BC: Loses & BA: Loses \\
\hline $\begin{array}{l}\text { 1- Extra expenses on buying } \\
\text { developed treatment equipment. } \\
\text { 2- Extra expenses on facilities } \\
\text { enhancements. } \\
\text { 3- They will buy more taxes } \\
\text { 4- Additional expenses to build } \\
\text { new irrigation network }\end{array}$ & \\
\hline
\end{tabular}

If we look at Tables $\mathrm{V}$, we can see that the dominant strategy for player 1 "BS" is to non-cooperate because " $6>3$, $5>2$ ", it's the same for player 2 "BA" because the non-cooperate strategy will also ensure him more profit no matter what player "BS" chooses.

Nash equilibrium is "non-cooperate, non-cooperate," which is basically the dominant strategy for both players, in the term that it is every player best strategy considering the 
other players' possible strategies.

TABLE IV: THE BENEFITS AND LOSSES FOR NON-COOPERATE-NON-COOPERATE N-N STRATEGY

\begin{tabular}{|c|c|}
\hline \multicolumn{2}{|c|}{$\mathrm{N}-\mathrm{N}$} \\
\hline BC: Benefits & BA: Benefits \\
\hline $\begin{array}{l}\text { 1- pollution will decrease, and lack } \\
\text { and basin view will enhance } \\
\text { 2- Tourism movement and } \\
\text { agricultural quality will enhance } \\
\text { 3- They will not buy developed } \\
\text { treatment equipment. } \\
\text { 4- They will not enhance their } \\
\text { facilities enhancements. } \\
\text { 5- Not building new irrigation } \\
\text { network (cut expenses). }\end{array}$ & $\begin{array}{l}\text { 1- Pollution will decrease (not as } \\
\text { much C-C strategy. } \\
\text { 2- Tourism movement and } \\
\text { agricultural quality will enhance } \\
\text { 3- Not building new irrigation } \\
\text { network (cut expenses). }\end{array}$ \\
\hline BC: Loses & BA: Loses \\
\hline 1- They will buy more taxes. & $\begin{array}{l}\text { 1- BS will not enhance their } \\
\text { facilities } \\
\text { 2- BS will not buy new } \\
\text { development equipment to treat } \\
\text { their wastes } \\
\text { 3- Public awareness will not } \\
\text { increase towards environmental } \\
\text { issues. }\end{array}$ \\
\hline \multicolumn{2}{|c|}{ Payoff (5-3) } \\
\hline
\end{tabular}

When both players choose a non-cooperate strategy, which means that "BA" will construct the project through private investor whom will construct the new sewage network and sewage treatment plants in exchange of investing these facilities for an agreed upon of time "under the BOT regulation." This will help "BA" to reduce the pollution rates coming from the residential areas, future industrial, and tourism facilities, but wastes from old industrial and tourism facilities will not stop completely. In the other hand, "BS" will not have to spend any money on enhancing their facilities and buying new advanced equipment to treat wastes, in exchange they will be demanded to buy more taxes under the new environmental regulations.

TABLE V: Payoffs Matrix, *NASH Equilibrium

\begin{tabular}{ccc}
\hline \hline \multicolumn{3}{c}{ Strategy (BA, BA) } \\
\hline Cooperate & Non-Cooperate \\
Cooperate & $(3-6)$ & $(2-6)$ \\
Non-Cooperate & $(6-2)$ & $(\mathbf{5 - 3}) *$ \\
\hline \hline
\end{tabular}

\section{Participatory Approach}

Depending on the game results which clarifies that the players will tend to choose "non-cooperate, non-cooperate" strategy, which is the best choice for both players in light of the other player strategies "Nash equilibrium."

This result maybe is the best for players, but it's not the case for environment and pollution levels, because despite that residential sewage will be treated, and new tourism and industrial facilities will have advanced waste treatment equipment designed to suit the new sewage network, but the existing old facilities will continue to dump their wastes in the basin. This will keep the basin pollution at the current level, maybe little less, and that will not be as the best result for national government vision to the coastal region generally, and for its lakes especially.

The national strategy for this region is to strengthen the agriculture and tourism movement in the basin, which is the primary planning assets, from an economic point of view, also of achieving the environmental/ecological security. Considering that, cooperating between local players "BA and BS" will be preferred in the eyes of the province-government, due to its effect in reducing the pollution level in the basin, protecting wildlife, including the plant cover, and achieving environmental sustainability. This will reflect on the tourism domain "eco-tourism, camping, resorts, restaurants, and hotels" and on the agricultural field "clean water for irrigation combined with the new advanced irrigation network", and intended investments in fish farms, which will increase the economic outcome of the whole region.

The province-government will encourage players to cooperate through multiple steps. The First Step; will be offering loans for basin's stakeholders "tourism and industrial" to help them buy the advanced waste treatment equipment, which will take the financial burden off the BS's shoulder. The second step will be the province-government plan for marketing the tourism in the area, especially the eco-tourism sector, taking advantage of the river basin natural resources "forests, lake, mountains, springs, waterfalls, and wildlife" in addition of pumping investments to build eco-hotels, camping facilities, and eco-resorts which will correspond to their plan in eco-security sector. Giving farmers loans to buy developed irrigation systems will be the third step, which will help them save water and protect arable land from salinity. The last step will also target the agricultural sector, through loans to build a new advanced irrigation network in addition of ensuring transportation channels to expand farmers market, because the current market is limited to the local or near area. This will help farmers to cover more markets in the country which will reflect an increase in their income and more investments in their infrastructure.

All these steps will help players to rethink their strategies in order to achieve a "cooperate- cooperate" strategy.

Otherwise, province-government will raise the taxes on "BS", which is not in the best interest of the "BS", mainly that they will compete with the other three basins in the province, in tourist and agricultural domains, who also have the same geographical and topographical features.

It's hard for the central government to deal with the local players, and districts or sub-districts, beside provinces in the same time to ensure the right execution of the regional strategy up-down, that's way participatory approach often play the main role in this case to achieve the benefits between players and local governments.

To reflect this strategy on game theory, we will change the rules of the previous game. In this case, decisions are not made simultaneously, rather in sequence, where stakeholders will take the first step in the game. This will transfer the game into its extensive form perfect information game.

\section{E. An Extensive Form of the Game}

Extensive form is different from the normal form, concerning the details each one can present. The extensive form can present more details regarding the amount of information every player knows before he makes his decision and the timing of that decision [17].

To solve this game in the extensive form we need to 
present it in a tree form. Tree graph will include nodes, the one in the root will be called initial node, and the ones at the end will be called terminal nodes where players receive payoffs. Nodes in between are called decision nodes, where every node represents a point where one of the players will make a move "decision". Branches, connects the nodes that are in the players' action set. The path is the sum of nodes and branches connecting the starting node with the end node [18].

As shown in Fig. 5, we can see that BS moves first, which is an implementation of participatory approach of the province-government. They have two strategies to choose from, either cooperate or non-cooperate. After "BS" moves, "BA" also has two strategies to choose from "c, n" depending on "BS" choice, due it's a perfect information game, so "BA" will know exactly what "BS" has chosen.

At the end of the extensive tree, we have the payoffs of the game. Thus, to analyze this kind of games, we have to find the Nash equilibrium by backward induction where we start from the end of the tree, going back with the rational decisions we assume that the player will make at every node, even for the nodes that we know he will never reach. Using back induction, we can see that in node "a1", "BA" will obviously choose "c" with the payoff " 6,6 ". In node "a2", "BA" have a unique situation with equal payoffs for either strategies, because both strategies have the same payoffs for them, but one of them is higher for "BS" than the other. We can assume here that "BA" will break the tie in favor of "BS" [19]. This will make the payoff in the node "a2", "5, 2". "BS" then will choose " $C$ " with the high payoff " 6,6 ", and that's the Nash equilibrium in this game.

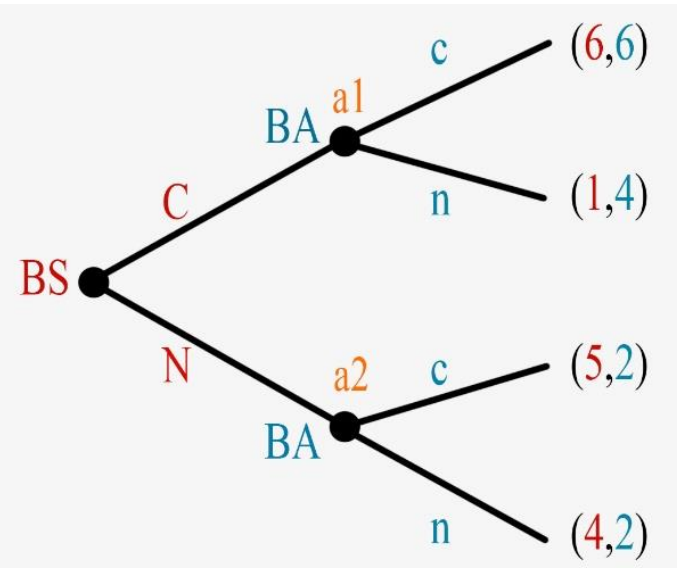

Fig. 5. The extensive form of the game.

This shows that with the province-government support, and all the motivations presented could contribute to pushing the coordination process to achieve cooperation between players, in order to make maximum profits for them and achieve its national strategy alike.

\section{CONCLUSION}

This paper presents a logical game-theoretic analytical model to analyze the behaviors of stakeholders in coordinating and managing mutual relations with water resources within the Al-Abrash basin in Syrian coastal region as a measurable geographic planning unit. Moreover, drawing conclusions to be applied in other similar areas "river basins/watersheds" taking into account the intervention of the governmental regulator at the local level, then at the provincial level.

At one hand the previous study falls within participatory approach as an application to build networks pattern between actors in a specific space, on the other hand, it also makes a new contribution at the state level in pursuing environmental protection within sensitive environments threatened by the risks resulting from human activities.

The analysis was in the form of simultaneous and sequence games with two players, and then, with the addition of the provincial government as a regulator. The results from the game show that the players will tend to choose non-cooperation strategy because of the lack of trust between them, and the shortage of full awareness of the huge future threat on their economic gains. Beside that cooperation will bring them an economic loss in the near future, though in the long term will bring them far more benefits.

Adding the provincial government effect in the next stage to the game, with a local development strategy based on innovating competitive planning policies between regions holding similar geographical and environmental high features, the results were indicating that players will lean towards cooperation strategy. Therefore the previous paper could be classified as one of the studies used to apply the participatory planning approach to achieve sustainable economic and environmental development.

At the end; this study is the first step concerning the economical environmental situation in the basin, this must be followed with further studies covering the citizen/inhabitant of the basin to achieve the integrated circular economy in the basin as a pilot region in Syria.

\section{ACKNOWLEDGMENT}

The authors acknowledge the financial support of Chongqing University. We are also immensely grateful to Tartous governor Mr. Safwan Abu Saada for administrative support, Also, for Eg. Zain Aldeen Yousef and the Directorate of Water Resources in Tartous.

\section{REFERENCES}

[1] W. M. Zhao et al., Theories of Human Settlements in Mountainous Regions (in Chinese), Chongqing: China Architecture\& Building Press, 2015 .

[2] T. Rahmoun, W. Zhao, M. Hammad, and M. Hassan, "Ruralization vs. Urbanization Sprawl as Guiding Regional Planning: Development Scenario for Rivers Watershed in the Southern Syrian Coastal Region,' IOP Conference Series Earth and Environmental Science, vol. 151, no. 1, Paris, France, 2018.

[3] T. B. H. Nyerges, C. Steinitz, T. Canfield, M. Roderick, J. Ritzman, and W. Thanatemaneerat, "Geodesign dynamics for sustainable urban watershed development," Sustainable Cities and Society, vol. 25, pp. 13-24, 2016

[4] W. M. Zhao et al., Researches on Human Settlements Construction in the Three Gorges: Theories and Practice (in Chinese), Beijing: CIP, 2013.

[5] S. Sarma and T. Saikia, "Prioritization of sub-watersheds in Khanapara-Bornihat area of Assam-Meghalaya (India) based on land use and slope analysis using remote sensing and GIS," Journal of the Indian Society of Remote Sensing, vol. 40, no. 3, pp. 435-446, 2012.

[6] T. C. Sheng, "Challenges and Strategies in Integrated Watershed Management in Developing Countries," Guide to the Papers of Ted C. Sheng. Series 1: Publications, 2016.

[7] B. Panigrahi and M. R. Goyal, Modeling Methods and Practices in Soil and Water Engineering, CRC Press, 2017. 
[8] K. Bruckmeier, "Interdisciplinary conflict analysis and conflict mitigation in local resource management," Journal of the Human Environment, pp. 65-73, 2005.

[9] J. R. Lund and R. N. Palmer, "Water resource system modeling for conflict resolution," Water Resources Update, pp. 70-82, 1997.

[10] F. Li, B. Pan, Y. Wu, and L. Shan, "Application of game model for stakeholder management in construction of ecological corridors: A case study on Yangtze River Basin in China," Habitat International, pp. 113-121, 2017.

[11] C.-S. Lee, "Multi-objective game-theory models for conflict analysis in reservoir watershed management," Chemosphere, pp. 608-613, 2012.

[12] T. Siegfried, A Beautiful Math: John Nash, Game Theory, and the Modern Quest for a Code, United States of America: Joseph Henry Press, 2006.

[13] J. Neumann and O. Morgenstern., Theory of Games and Economic Behavior, Princeton University Press, 2007.

[14] R. B. Myerson, "NASH equilibrium and the history of economic theory," Journal of Economic Literature, 1999.

[15] S. Zara, F. Patrone, and A. Dinar, "Cooperative game theory and its application to natural environmental and water resource issues: 2," Application to Natural and Environmental Resources, World Bank Publications, 2006

[16] I. Parrachino, Cooperative Game Theory and Its Application to Natural, Environmental and Water Resource Issues, World Bank Publications, 2006.

[17] G. Romp, Game Theory: Introduction and Applications, Oxford University Press, 1997.

[18] E. Rasmusen, Games and Information, Third Edition An Introduction to Game Theory, Blackwell Publishers, 2001.

[19] J. Letchford, V. Conitzer, and K. Jain, "An "ethical" game-theoretic solution concept for two-player perfect-information games,"
International Workshop on Internet and Network Economics, Berlin, Heidelberg, 2008.

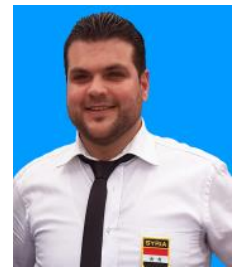

Tarek Rahmoun was born in Safita city, Tartous province, Syria in 1982. He is holding a Ph.D. of regional planning \& sustainable development. He worked as a research assistant from 08/2009 to 09/2013, Department of urban planning \& environment, Tishreen University, Lattakia. Syria, and Teaching Assistant from 08/2006 to 09/2009, at the same institute. He participated in many conferences like AURG 2016, Makassar, Indonesia; UPADSD 2017, Palermo. Italy; CST 2017 Thessaloniki, Greece; ICESD 2018, Paris, France. Also, He published papers in the field of urban-rural development and environmental issues.

Dr. Tarek awarded 2018 outstanding international graduate $\mathrm{PhD}$ student of Chongqing University, and the first place at the Ph.D. forum which held in Chongqing University, faculty of architecture and urban Planning, 2015, also, the first place for the B.Sc. in Architecture, 2005. Tishreen University, Lattakia. Syria.

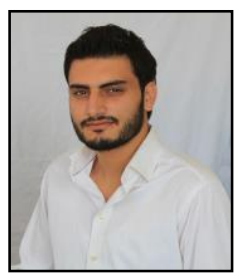

Mohammed Rahmoun was born in Mahweet city, Yemen in1991. He is architect. His major is sustainable architecture. He is master candidate, at Chongqing University, Faculty of Architecture and Urban Planning.

$\mathrm{He}$ is under full-time Master student since 9/2017 until 8/2018. He held a bachelor degree in architecture from Tishreen University, Lattakia, Syria. 